21 Giafi CF, Rumsby G. Kinetic analysis and tissue distribution of human D-glycerate dehydrogenase/glyoxylate reductase and its relevance to the diagnosis of primary hyper104-9.

22 Cramer SD, Ferree PM, Lin K, Milliner DS, Holmes RP. The gene encoding hydroxypyruvate reductase (GRHPR) is mutated in patients with primary hyperoxaluria type II. Hum Mol Genet 1999;8:2063-9.

23 Kemper MJ, Conrad S, Müller-Wiefel DE. Primary hyperoxaluria type 2. Eur $\mathcal{F}$ Pediatr 1997;156:509-12.
24 Leumann $\mathrm{E}$, Hoppe $\mathrm{B}$. What is new in primary hyperoxaluria? Nephrol Dial Transplant 1999;14:2556-8.

25 Milliner DS, Wilson DM, Smith LH. Clinical expression and long term outcomes of primary hyperoxaluria types 1 and 2. F Nephrol 1998;11(suppl 1):56-9.

26 van Acker KJ, Eyskens FJ, Espeel MF, et al. Hyperoxaluria with hyperglycolaturia not due to alanine: glyoxylate aminotransferase defect: a novel type of primary hyperoxaluria. Kidney Int 1996;50:1747-52.

\title{
EUROPE CALLING
}

Unnoted by the great majority of the general paediatric community, the " 5 th International Conference on Pediatric ORL" scheduled to be held in Graz, Austria, 9-12 July 2000 , has been cancelled. In his letter to those colleagues organising scheduled symposia, the congress chairman, Prof Stammberger, head of the department of head and neck surgery at the University of Graz, bitterly regretted this unforeseen development.

What had happened? Obviously, the current political situation in Austria had resulted in the several international pharmaceutical companies withdrawing their participation in the meeting, shortly after a new government had been elected to include the ultranationalist Jörg Haider's FPÖ (Liberal Party of Austria). One may argue whether it is politically correct to participate in an international medical convention in a country whose government contains politicians from a party whose leader (Haider himself is not a member of the government) has repeatedly expressed antisemitic and other discriminating statements. However, international medical meetings used to be and are still being held in non-democratic countries (which Austria is not) with financial support from the pharmaceutical industry and generally without boycott from potential attendees.

It is sad that scientific exchange- that is, the realisation of a long planned European meeting, has to suffer from the admittedly unwelcome political development in Austria. What is of concern is the fact that it was not the scientist's decision to refrain from participation but that of the sponsors from the pharmaceutical industry, who feared for their international reputation. Today, most national and virtually all large international medical conventions depend on direct (sponsoring of speakers) and indirect (through participation in parallel exhibitions) financial support by industry. Probably, there is little we can do about it and usually this is acceptable as long as the organising committees remain independent. But at least it should be a warning for all future organisers of meetings to be alert when they sign contracts with sponsors.

ULRICH HEININGER

European Associate Editor 